\title{
Calliandra ricoana (Leguminosae, Mimosoideae, INGEAE): A NEW AND CRITICALLY ENDANGERED SPECIES fROM ChIAPAS, MeXico
}

\author{
Héctor M. Hernández ${ }^{1,4}$, Rodrigo Duno de Stefano², Celso Gutiérrez ${ }^{3}$, \\ Germán Carnevali-Fernández-Concha ${ }^{2}$, Lilia L. Can² and Eliseo PoOl ${ }^{2}$ \\ 'Departamento de Botánica, Instituto de Biología, Universidad Nacional Autónoma de México, México, D.F., Mexico \\ ${ }^{2}$ Herbario $\mathrm{CICY}$, Centro de Investigación Científica de Yucatán, A.C., Mérida, Yucatán, Mexico \\ ${ }^{3}$ Herbario UCAM, Centro de Investigaciones Históricas y Sociales, Universidad Autónoma de Campeche, \\ San Francisco de Campeche, Campeche, Mexico \\ ${ }^{4}$ Corresponding author: hmhm@ib.unam.mx
}

\begin{abstract}
Calliandra ricoana, a new species of Leguminosae (Mimosoideae, Ingeae), from the state of Chiapas, Mexico, is described and illustrated. Critical examination of C. ricoana in comparison with members of Calliandra section Androcallis, series $M a$ crophyllae shows that it is morphologically similar and presumably closely related to C. macqueenii and C. trinervia var. arborea, but it can be distinguished from these and the other members of the series by a combination of characters, namely the arborescent habit, relatively larger leaflets, short peduncles, homomorphic flowers, longer corollas and longer, exserted staminal tubes.
\end{abstract}

Key words: Fabaceae, sect. Androcallis, ser. Macrophyllae, tropical trees.

Resumen: Se describe e ilustra a Calliandra ricoana, una nueva especie de Leguminosae (Mimosoideae, Ingeae), del estado de Chiapas, México. El examen crítico de C. ricoana en comparación con los miembros de Calliandra sección Androcallis, serie Macrophyllae muestra que la nueva especie es morfológicamente similar y, presumiblemente, estrechamente relacionada con $C$. macqueenii y $C$. trinervia var. arborea, pero puede ser distinguida de éstos y los demás miembros de la serie por una combinación de caracteres; a saber, el hábito arborescente, los folíolos relativamente más grandes, los pedúnculos cortos, las flores homomórficas, la corola más larga y los tubos estaminales más largos y exertos.

Palabras clave: Fabaceae, secc. Androcallis, ser. Macrophyllae, árboles tropicales.

$\mathbf{T}$ he tribe Ingeae Benth. comprises 36 genera and about one thousand species (Lewis and Rico Arce, 2005). Ingeae differs from other tribes of the subfamily because the stamens are basally united in a tube of variable length. $\mathrm{Ca}$ lliandra Benth. is readily distinguished from other genera of Ingeae by its elastically dehiscent fruits, also found in Zapoteca H. Hern. (Hernández, 1986) and Calliandropsis H. Hern. et Guinet (Hernández and Guinet, 1990), its 8grained, bisymmetric, calymmate polyads, with columellar/ granular exine structure, and a mucilaginous structure on the "basal" cell (Guinet and Hernández, 1989), and by its atypical chromosome numbers ( $n=8$ and 11), which contrast with the consistent basic chromosome number $(\mathrm{X}=13)$ found in the remaining members of the tribe (Hernández,
1986, 1989). In addition, Prenner (2004), and Prenner and Teppner (2005) found several floral ontogenetic characters in $C$. angustifolia Spruce ex Benth. (e.g., unidirectional sepal initiation, cochlear descending sepal aestivation, helical androecium initiation and a particular mode of pollen presentation), providing further evidence for the isolated character of the genus.

The latest comprehensive account of Calliandra was produced by Barneby (1998), who recognized approximately 130 species ranging from southwestern United States of America to northern Uruguay, Argentina and Chile, including most of Mexico, Central America, South America and the Antilles. More recently, Souza et al. (2013) constructed a phylogeny of the genus using morphological and molecu- 


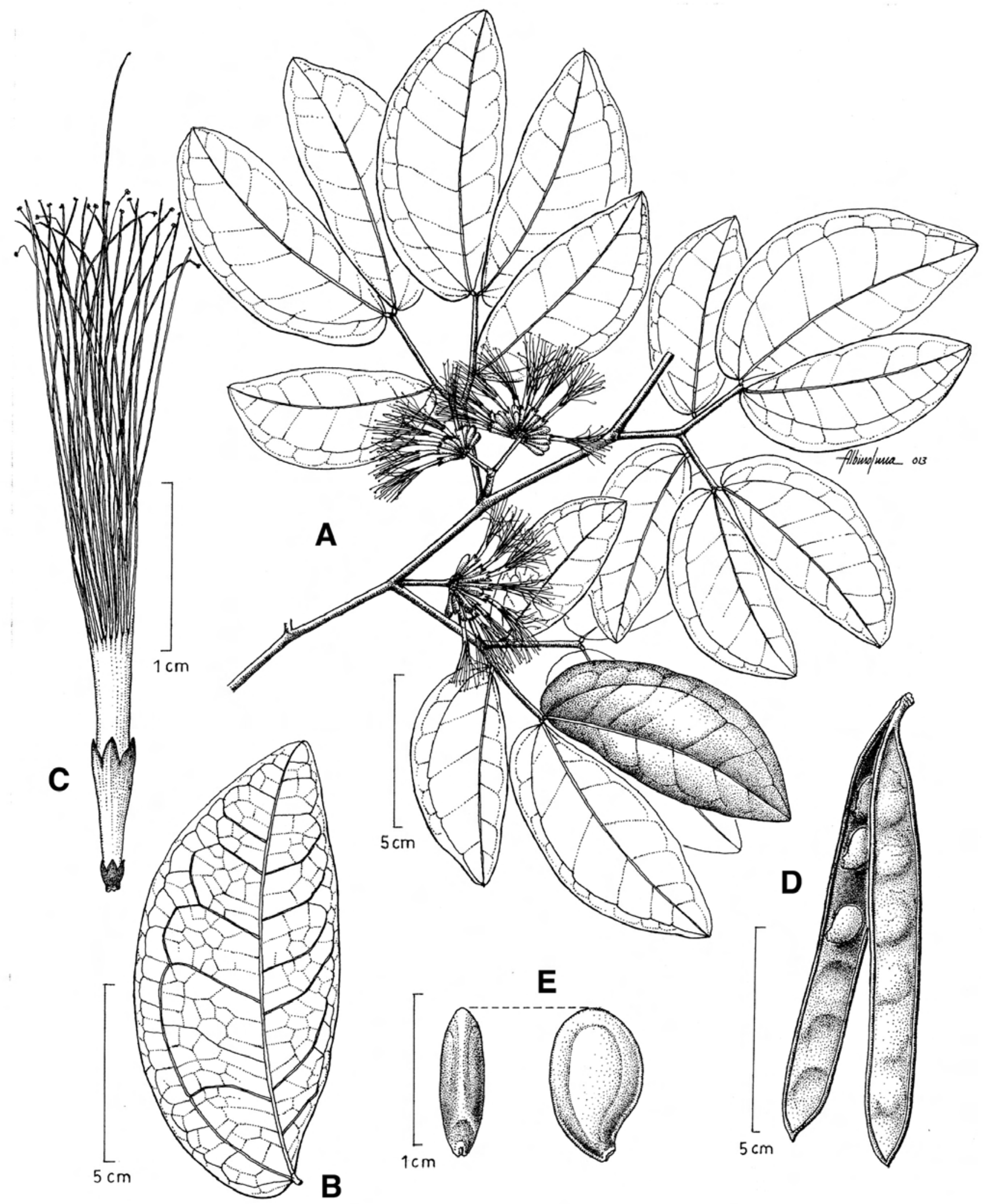

Figure 1. Calliandra ricoana H. Hern. et R. Duno. A) Branchlet with inflorescence at anthesis. B) Leaflet. C) Flower showing the exserted staminal tube. D) Pod. E) Seeds. Drawn by Albino Luna: A-C from Breedlove and Davidse 55360 (MEXU), D-E from Wendt et al. 2327 (holotype, MEXU). 
lar data [nrDNA sequences (ITS) and cpDNA (trnL-F)]. She concluded that the New World Calliandra species, together with genus Guinetia L. Rico et M. Sousa (Rico Arce et al., 1999), but excluding the two African species, conform a monophyletic group. Here, we propose $C$. ricoana, a new species belonging to section Androcallis Barneby, series Macrophyllae Benth.

Calliandra ricoana H. Hern. et R. Duno, sp. nov. (Figure 1).

Shrubs or small trees to 6(-10) $\mathrm{m}$ tall. Leaves bipinnate, without extrafloral nectaries; pinnae 1 pair; leaflets 3 per pinna, the distal ones larger, (7.6-)10-13 × (2.8-)3.5-5.6 cm. Inflorescence a hemispherical head; peduncles 3-17 mm long; receptacle not elongate, $2 \mathrm{~mm}$ long. Flowers homomorphic; calyx (1-)2-4 mm long, campanulate; corolla 9$18 \mathrm{~mm}$ long, tubular or tubular-infundibuliform; filaments white in the basal half, reddish in the distal half; staminal tube conspicuously exserted in all flowers, $14-38 \mathrm{~mm}$ long. TYPE: Mexico, Chiapas, municipio de Palenque, $11.4 \mathrm{~km}$ al S de Palenque, sobre carretera a Ocosingo (carr. 199), 2 $\mathrm{km}$ al S del entronque con carretera a Chancalá (carr. 192), $17^{\circ} 27^{\prime}$ lat. $\mathrm{N}, 91^{\circ} 59^{\prime}$ long. W, alt. 300-330 m, selva alta perennifolia, lomas empinadas, suelo margoso con lutitas, arbusto o arbolito de hasta $4 \mathrm{~m}$, frecuente en lugares abiertos, 2 Diciembre 1979 (flower, fruit), T. Wendt, E. Lott and J. García 2327 (holotype: MEXU; isotypes: CAS, CHAPA, ENCB).

Shrubs or small trees to $6(-10) \mathrm{m}$ tall; stems to $12 \mathrm{~cm}$ diam. at the base; young branches glabrous; stipules $1.8-3 \mathrm{~mm}$ long, triangular to ovate, membranous, glabrous, deciduous. Leaves bipinnate, glabrous throughout, without extrafloral nectaries; pinnae 1 pair; petioles $1.5-6.2 \mathrm{~cm}$ long, with a conspicuous ventral channel; rachis lacking; rachilla 2-3.5 cm long, with a conspicuous ventral channel; leaflets 3 per pinna, the distal ones larger, (7.6-)10-13 × (2.8-)3.5-5.6 $\mathrm{cm}$, inequilaterally elliptic or elliptic-lanceolate, base oblique, the narrow size cuneate, the wide size lobate, acute to short-acuminate, coriaceous, blade light green in the abaxial face, dark green and lustrous in the adaxial face; venation brochidodromous, with 2(-3) prominent veins arising from the base, the thicker vein excentric and slightly incurved, the higher order veins and reticular veinlets weakly raised on both faces. Inflorescence a hemispherical head, 12-30 flowered; peduncles axillary, solitary or fasciculate, 3-17 mm long; receptacle not elongate, $2 \mathrm{~mm}$ long; bracts spathulate, concave, $\pm 1.5-2.3 \mathrm{~mm}$ long, persistent. Flowers homomorphic, apparently diurnal, sessile; calyx (1-)2-4 mm long, campanulate, teeth deltate, membranous, glabrous to sparsely puberulent, light green to reddish; corolla 9-18 mm long, tubular or tubular-infundibuliform, membranous, glabrous to sparsely puberulent, light green to reddish; filaments (40-)50$62 \mathrm{~mm}$ long, 24-26-merous, white in the basal half, reddish in the distal half; staminal tube conspicuously exserted in all flowers, 14-38 mm long; anthers dorsifixed, transversally oblong to elliptic; polyads 8 -grained, \pm ellipsoid, with two central grains and six heteromorphic peripheral grains, peripheral grains variously angled, each central pollen grain with 4 perimetral pori, ectexine verrucose; ovary glabrous. Pods pendulous, solitary or rarely 2 per capitulum, elastically dehiscent, usually $7-11.3 \times 1-1.2 \mathrm{~cm}$, linear, flattened, with thick marginal suture ribs, base attenuate, apex obtuse to rounded with a short mucron, rigidly membranous, glabrous. Seeds 3-6 per pod, on short dilated funiculus, compressed-ovoid, pleurogram inconspicuous.

Distribution and ecology. Calliandra ricoana appears to be restricted to two small areas in northeastern Chiapas, Mexico: one south of Palenque (municipality of Palenque) and the other in the vicinity of Agua Azul waterfalls (municipality of Tumbalá), at 300-450 m elevation (Figure 2). Unfortunately, the area, originally covered by dense tropical evergreen forest, has been almost completely deforested, although small forest fragments still remain. However, the plant seems to be abundant in the area as indicated in the herbarium specimen label (Wendt et al. 2327).

Phenology. Flowering occurs between August and January, and fruiting between September and January.

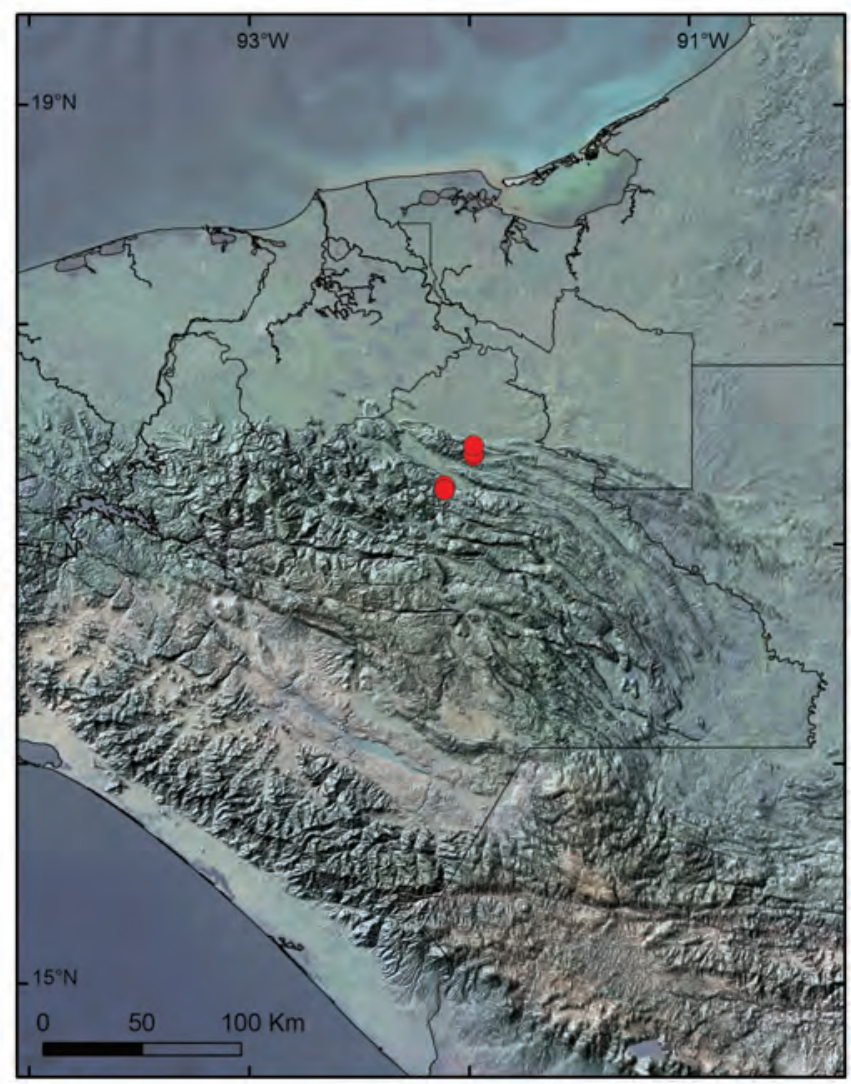

Figure 2. Geographical distribution of Calliandra ricoana (red dots). 
HÉCTOR M. HERNÁNDEZ ET AL.

Table 1. Morphological comparison of Calliandra ricoana and related taxa. Most character states of C. macqueenii and C. trinervia var. arborea were taken from Barneby (1998).

\begin{tabular}{llll}
\hline & C. ricoana & C. macqueenii & C. trinervia var. arborea \\
\hline Habit & shrubs, small trees & shrubs & shrubs, small trees \\
Maximum height $(\mathrm{m})$ & $6(-10)$ & 1.5 & 9 \\
Leaflets per pinna & 3 & 4 & $3-4$ \\
Leaflet length $(\mathrm{cm})$ & $(7.6-) 10-13$ & $2.2-5$ & $(4.5-) 6.5-11$ \\
Leaflet width $(\mathrm{cm})$ & $(2.8-) 3.5-5.6$ & $0.9-2.2$ & $1.4-5$ \\
Peduncle length $(\mathrm{mm})$ & $3-17$ & $2.5-5$ & $14-36$ \\
Receptacle & not elongate $(2$ mm long) & elongate (5-7 mm long) & not elongate (1-3 mm long) \\
Flowers & homomorphic & homomorphic & heteromorphic \\
Calyx length $(\mathrm{mm})$ & $(1-) 2-4$ & $1.9-2.3$ & $1.2-3.4$ \\
Corolla length $(\mathrm{mm})$ & $9-18$ & $9-10$ & $6.4-7.5(-13)$ \\
Staminal tube & exserted in all flowers & exserted in all flowers & included or shortly exserted in peripheral \\
& & & flowers, exserted in central flowers \\
Staminal tube length $(\mathrm{mm})$ & $14-38$ & $15-16$ & $4.5-7.5$ \\
Stamen length $(\mathrm{mm})$ & $(40-) 50-62$ & 40 & $19-33$ \\
Stamen color & white/reddish & creamy-white & pink, red, exceptionally white \\
Pod size (cm) & $7-11.3 \times 1-1.2$ & $(6-) 8-14 \times 0.65-0.8$ & $8.5-18 \times 1.1-1.7$ \\
\hline
\end{tabular}

Etymology. We take pleasure in naming this new species to honor our friend and colleague, Dr. María de Lourdes Rico Arce, recognizing her numerous contributions to our knowledge of the Leguminosae.

Conservation status. Accurate information regarding the distribution area and population dynamics of C. ricoana is lacking. However, according to the IUCN Red List criteria (IUCN, 2001), the category of Critical Endangered (CR) may be provisional assigned in view of its apparently narrow distribution range (only two known populations) and considering that the suitable habitat necessary for its survival is almost totally destroyed.

Morphological comparasion. Calliandra ricoana is a remarkable member of Calliandra series Macrophyllae Benth., which, according to Barneby (1998), includes 12 species of macrophyllous trees and shrubs, with leaves consistently bearing a single pair of pinnae, each with one to four, large (mostly 4-19 cm long) leaflets. The new species appears to be closely related to $C$. macqueenii Barneby, also a member of ser. Macrophyllae, known only from a restricted locality of Guerrero. Calliandra ricoana and C. macqueenii have in common the short peduncles, the relatively long corollas, as well as the long exserted staminal tubes. However, C. ricoana may be easily distinguished by being larger shrubs or small trees, by the pinnae with 3 larger leaflets, by the not elongate receptacle, and by the larger flower parts (corolla, staminal tube, and filament) and different filament color (Table 1). Another presumably close relative of $C$. ricoana is $C$. trinervia Ben- th. var. arborea (Standley) Barneby, which is also present in Chiapas and elsewhere in Central America (Barneby, 1998; Hernández, 2001; Zamora, 2010). These two taxa share the arborescent habit, the significantly large leaflets and the inflorescences with essentially spherical, not elongated receptacles. However, $C$. ricoana may be easily distinguished from that species by having shorter (3-17 mm) peduncles, homomorphic flowers, usually longer corollas, and longer and exserted staminal tubes in all flowers of the inflorescence. Calliandra trinervia var. arborea usually has longer (14-36 mm) peduncles, inflorescences with heteromorphic -central and peripheral- flowers, shorter corollas (except in the central flowers), and shorter, inserted staminal tubes in the peripheral flowers (Table 1).

Additional specimens examined. Mexico. Chiapas, municipality of Palenque: $6-12 \mathrm{~km} \mathrm{~S}$ of Palenque on road to Ocosingo, 300m, D.E. Breedlove 26540 (MEXU), D.E. Breedlove 28816 (DS, MEXU); 9-12 km S of Palenque on road to Ocosingo, $300 \mathrm{~m}$, D.E. Breedlove and G. Davidse 55360 (MEXU); $10 \mathrm{~km} \mathrm{~S}$ of Palenque towards Ocosingo, $17^{\circ} 24^{\prime} 15^{\prime}$ ' lat. N, $91^{\circ} 59^{\prime} 30^{\prime \prime}$ long. W, 330 m, C. Gutiérrez Báez 6016 (MEXU); $15 \mathrm{~km} \mathrm{~S}$ of Palenque on road to Ocosingo, $17^{\circ} 25^{\prime}$ lat. $\mathrm{N}, 91^{\circ} 59^{\prime}$ long. W, $300 \mathrm{~m}, D$. Macqueen 327 (EAP, FHO, K, MEXU, NY), $11 \mathrm{~km} \mathrm{SE} \mathrm{of}$ Palenque, $O$. Téllez and E. Martínez 820 (MEXU). Municipality of Tumbalá: Agua Azul, $17^{\circ} 16^{\prime} 00^{\prime \prime}$ lat. N, $92^{\circ}$ 07' 00" long. W, 450 m, C. Gutiérrez Báez 8292 (UCAM); Cascadas de Agua Azul, $17^{\circ} 14^{\prime}$ 52" lat. N, 92 06' 54" long. W, 296 m, C. Gutiérrez Báez 10840 (CICY, MEXU, MO, UCAM). 


\section{Acknowledgements}

The authors are indebted to the curators of CICY, MEXU and XAL herbaria for making available the herbarium material necessary for this study. We thank Silvia Hernández (CICY) for providing bibliography and additional support, Albino Luna (IBUNAM) for the botanical illustration, Carlos Gomez-Hinostrosa for the distribution map and two anonymous reviewers for helpful comments to the original manuscript. The research presented here was funded by a grant from the Consejo Nacional de Ciencia y Tecnología, Mexico to Rodrigo Duno (81799).

\section{Literature cited}

Barneby R.C. 1998. Silk tree, guanacaste, monkey's earring: a generic system for the synandrous Mimosaceae of the Americas. Part III. Calliandra. Memoirs of the New York Botanical Garden 74:1-223.

Guinet Ph. and Hernández H.M. 1989. Pollen characters in the genera Zapoteca and Calliandra (Leguminosae, Mimosoideae) and their systematic and phylogenetic relevance. Pollen et Spores 31:5-22.

Hernández H.M. 1986. Zapoteca: a new genus of Neotropical Mimosoideae. Annals of the Missouri Botanical Garden 73:755763.

Hernández H.M. 1989. Systematics of Zapoteca (Leguminosae). Annals of the Missouri Botanical Garden 76:781-862.

Hernández H.M. 2001. Calliandra. In: Stevens W. D., Ulloa C., Pool A. and Montiel O. M. Eds. Flora de Nicaragua. Vol. II, pp. 1457-1460, Missouri Botanical Garden Press, Saint Louis Missouri.

Hernández H.M. and Guinet Ph. 1990. Calliandropsis: a new genus of Leguminosae: Mimosoideae from Mexico. Kew Bulletin 45:609-620.

IUCN. International Union for Conservation of Nature and Natural Resources. 2001. IUCN Red List categories and criteria: version 3.1. IUCN Species Survival Commission. Gland.

Lewis G.P. and Rico Arce L. 2005. Tribe Ingeae. In: Lewis G.P., Schrire B., Mackinder B. and Lock M. Eds. Legumes of the World, pp. 193-213, Royal Botanic Gardens Kew, London.

Prenner G. 2004. Floral ontogeny in Calliandra angustifolia (Leguminosae: Mimosoideae: Ingeae) and its systematic implications. International Journal of Plant Science 165:417-426.

Prenner G. and Teppner H. 2005. Anther development, pollen presentation and pollen adhesive of parenchymatous origin in Calliandra angustifolia (Leguminosae-Mimosoideae-Ingeae). Phyton 45:267-286.

Rico Arce M.L., Sousa M. and Fuentes S.S. 1999. Guinetia: a new genus in the tribe Ingeae (Leguminosae: Mimosoideae) from Mexico. Kew Bulletin 54:975-981.

Souza E.R. de, Lewis G.P., Forest F., Schnadelbach A.S., van den Berg C. and de Queiroz L.P. 2013. Phylogeny of Calliandra (Leguminosae: Mimosoideae) based on nuclear and plastid molecular markers. Taxon 62:1200-1220.

Zamora N. 2010. Fabaceae. In: Hammel B.E., Grayum M.H., Herrera C. and Zamora N. Eds. Manual de Plantas de Costa Rica. Vol. V. Dicotiledóneas (Clusiaceae-Gunneraceae), Monographs in Systematic Botany from the Missouri Botanical Garden 119:395-775.

Received: September 10th, 2013

Accepted: November 11th, 2013 